\title{
Effect of Alternative Scouring Agents on Dyeing Properties of Cotton/Polyester Blend Fabric
}

\author{
D. E.A. Boryo ${ }^{1 *}$; K.A. Bello ${ }^{2}$; A.Q. Ibrahim ${ }^{3}$; N.S Gin ${ }^{4}$; T.M. Dauda ${ }^{1}$ and \\ V.O. Elabo'. \\ ${ }^{I}$ Science Laboratory Technology Department, Federal Polytechnic PMB 0231 Bauchi Nigeria. \\ ${ }^{2}$ Textile Technology Department, Ahmadu Bello University, Zaria Nigeria. \\ ${ }^{3}$ Chemistry Programme, Abubakar Tafawa Balewa University PMB 248 Bauchi Nigeria. \\ ${ }^{4}$ Science Laboratory Technology Department, Abubakar Tatari Ali Polytechnic Bauchi Nigeria
}

\begin{abstract}
This research comprises of six alternative agents $\left(\left(\mathrm{NH}_{4}\right)_{2} \mathrm{C}_{2} \mathrm{O}_{4}\right.$, liquid $\mathrm{NH}_{3}, \mathrm{CH}_{3} \mathrm{COOH}, \mathrm{NH}_{4} \mathrm{OH}$, $(\mathrm{COOH})_{2}, \mathrm{CH}_{3} \mathrm{CH}_{2} \mathrm{OH}$ ) at various concentrations of $1-5 \%$ used as scouring agents with $\mathrm{NaOH}$ as control on cotton/polyester blend fabric. The samples were bleached, mercerized and dyed. The suitability and reliability of the agents were evaluated for dyeing properties of the treated fabric. Water imbibing properties of the treated fabric, was investigated. The experimental results showed that the percentage exhaustion of indigo dye on the treated fabric were wonderful with values far above average (86.8-62.6\%) except for $1 \%\left(\mathrm{NH}_{4}\right)_{2} \mathrm{C}_{2} \mathrm{O}_{4}$ that recorded slightly below average $(49.7 \%)$. $2 \%$ liquid $\mathrm{NH}_{3}$ ranked the highest. The wash fastness is another interesting results where only $1-5 \%$ liquid $\mathrm{NH}_{3}, 2 \%$ and $4 \%\left(\mathrm{NH}_{4}\right)_{2} \mathrm{C}_{2} \mathrm{O}_{4}$ that gave a grey scale rating for wash fastness of 4 (very good). The other alternative agents strongly competed at various concentrations with the control which revealed a rating of 5 (excellent wash fastness). $4 \%\left(\mathrm{NH}_{4}\right)_{2} \mathrm{C}_{2} \mathrm{O}_{4}$ scoured fabrics recorded the highest water of imbibitions $(2.9 \mathrm{~g})$. This implies that the alternative agents are suitable and reliable as impurity-removing (scouring) agents. The alternative agents improved the dyeing and water imbibing properties of the treated fabric far better than the control. Therefore could be employed in the textile industry.
\end{abstract}

Keywords: alternative scouring agents, percentage exhaustion, reliable, suitable, wash fastness, water of imbibitions.

\section{INTRODUCTION}

It is necessary to carry out some preparatory treatments before the application of other finishing processes to the newly constructed fabric. Any remaining impurities must be removed and additives used to facilitate the manufacturing process must also be removed [1]. Some of the most frequent pretreatment processes include; scouring, bleaching and mercerization [1].

It has been established by many researchers such as [2, 3, and 4] that during scouring fatty acids are converted to soap which helps to emulsify other wax-like substances. Caustic soda $(\mathrm{NaOH})$ hydrolyses protein and the molecules are broken along peptide links with the formation of alkali soluble amino acids. Similarly, pectin and lignin are hydrolyzed, gradually destroyed or decomposed to soluble salts.

After scouring, the fabric gives better wetting and penetration properties. This makes the subsequent bleaching and mercerization processes easy resulting in better dye intake and improved mechanical properties. Caustic soda has been used at $2 \%$ to achieve this process [5].

After all these chemical treatments, fabrics are usually dyed. Life is good they say, when everything desired are falling in line. Imagine the reason why "Immaculate" white materials are not worn, if not on occasions. This is because colour is good and is desired by all and sundry. The desire for a given fabric lies on its colour (appearance), texture (quality) and so on. Therefore dye is among the treatment that furnishes fabric to make it desirous and loving by all. Colour retention after dyeing is an important parameter in textiles. Colour is often the primary consideration when purchasing clothing and household textiles. When the colour fades or streaks, items are discarded before they are worn out. There are numerous dyes in use, but this work is interested in using indigo. It is classified as historical dye, and has retained its importance up to the present day. From practical indigo dyed cloths such as aizome to modern fashionable jeans, indigo has always had a wide field of application. Moreover, the chronic and acute toxicity of indigo is very low [6]. Indigo which is vat dye, has an affinity for cotton, wool and silk fabrics in its leuco form, but it has a low affinity for synthetic fabrics such as polyester [6]. This author investigated the possibility of dyeing synthetic fabric (polyester) with indigo using the cotton dyeing method but it was not possible. However, the author recently demonstrated the possibility of dyeing polyester fabrics with indigo by controlling the ratio of sodium hydrosulphite and $\mathrm{NaOH}$ concentration in the dye bath solution at a mild temperature. The author also applied the method for cotton fabric with great 
success. However, there is no information on the application of this method on cotton/polyester blends. This present work developed the interest to apply the method on cotton/polyester blend.

However, scouring with strong alkaline $(\mathrm{NaOH})$ is considered by [7] as pollution process, since it required a large quantity of waste and generates alkaline effluent. Furthermore, the resulting waste solution has high chemical oxygen demand (COD), biological oxygen demand (BOD) and salt content as investigated by [3]. Such waste water when in contact with a water body, may change the $\mathrm{pH}$ of an aquatic ecosystem, causing damage to aquatic life [8]. The natural $\mathrm{pH}$ of aquatic ecosystems can vary significantly among aquatic ecosystems, optimum conditions for aquatic organisms as reported by [8]ranged from 6 up to 9 . Therefore, this demands for more friendly alternative scouring agents. This scouring process in presence of oxygen and at higher concentration and or temperature may result in serious shrinkage, swelling and oxycellulose formation which damages the fibre/fabric and affect the mechanical properties [2 and 3] There is no much work on other alkalis or alternative agents suggested. However, the use of ammonium oxalate by [9] has proved to produce better mechanical properties on bast fibre than the traditional sodium hydroxide. Further findings by [10] proved the use of alternative agents for scouring with improved mechanical properties suitable, reliable, cheaper and more environmentally friendly $\mathrm{pH}$ of the scouring effluents of scouring than the commercial $\mathrm{NaOH}$. These findings contributed a part to the birth of this present work.

The specific objectives are to determine the optimum alternative scouring agents with:

$>$ Better dyeing properties such as degree of percentage exhaustion and wash-fastness.

$>$ Improved water of imbibition.

$>$ Thus, this research aim at improving on the quality of Nigerian made fabrics which is in line with the vision of repositioning of Nigeria, that is "vision 20:20:20"

\subsection{Sample Collection and Preparation}

\section{Experimental}

The sample cotton/polyester blend fabrics were obtained from Funtua Textile Company Ltd. in Katsina, State Nigeria. While indigo dye was bought from Kano, Nigeria in a chemical shop at the main market. The samples were cut into pieces with dimension $10 \mathrm{~cm}$ length by $10 \mathrm{~cm}$ width and kept in the laboratory before treating chemically.

\subsection{Methods}

The cotton / polyester blend fabrics were scoured, bleached and mercerized according to standard methods as described below.

\subsubsection{Scouring Process:}

- Scoured by the standard method described by [2] and [5].

- Using $1 \%, 2 \%, 3 \%, 4 \%$ and $5 \% \mathrm{NaOH} \mathrm{w} / \mathrm{v}$ (as control) fabrics were separately immersed and boiled for 1 hour for each solution.

- The process was repeated using the alternative agents $-\mathrm{NH}_{4} \mathrm{OH},\left(\mathrm{HN}_{4}\right)_{2} \mathrm{C}_{2} \mathrm{O}_{4},(\mathrm{COOH})_{2}, \mathrm{CH}_{3} \mathrm{COOH}$, liquid $\mathrm{NH}_{3}$ and $\mathrm{CH}_{3} \mathrm{CH}_{2} \mathrm{OH}$ each at the various concentrations of 1 to $5 \%$ separately.

\subsubsection{Bleaching Process:}

- Scoured samples were bleached using $4 \mathrm{~g} / 1 \mathrm{NaClO}_{2}$ solution according to the procedure described by [2].

\subsubsection{Mercerization Process:}

- The bleached samples were mercerized with $22 \% \mathrm{NaOH}$ below $5^{\circ} \mathrm{C}$ for 45 minutes in accordance to standard methods of [2] and [5].

\subsection{Evaluation of the effect of alternative scouring agents}

\subsubsection{Determination of Degree of Percentage Exhaustion:}

- Dyeing was carried out as described by [6,11 and 12]. A stock solution of $1 \mathrm{~g}$ indigo dye was prepared with $2 \mathrm{~g} \mathrm{Na}_{2} \mathrm{~S}_{2} \mathrm{O}_{4}$ and $0.25 \mathrm{~g} \mathrm{NaOH}$ as dye assistants in $250 \mathrm{ml}$ volumetric flask

- Dyeing was carried out at $120^{\circ} \mathrm{c}$ for 30 minutes at $1 \%$ dyeing

$$
\begin{array}{ll}
\text { Volume of dye stock }=\frac{W X P}{C} \\
\mathrm{~W}= & \text { Weight of fabric sample } \\
\mathrm{P} \quad= & \text { Percentage dyeing required }=1 \% \text { dyeing } \\
\mathrm{C} \quad= & \text { Percentage concentration of stock solution }
\end{array}
$$




$$
=\quad \frac{1}{250} \times 100=0.4
$$

- 40:1 liquor to material ratio was carried out

- The amount of dye absorbed was measured and recorded with an ultra violet spectrophotometer (Prolabo 320RD) at wavelength 605nm [6]

- Degree of percentage exhaustion was calculated using

$$
\begin{array}{ll}
\% \text { Exhaustion }= & \frac{A_{O}-A_{t}}{A_{O}} \\
\mathrm{~A}_{\mathrm{O}}= & \text { Initial absorbance } \\
\mathrm{A}_{\mathrm{t}}= & \text { Absorbance at time } \mathrm{t} .
\end{array}
$$

\subsubsection{Determination of Wash fastness:}

- Dyeing was carried out in accordance with the method of [6,11 and 12]

- $3 \%$ dyeing was carried out at liquor to material ratio of $40: 1$ at $120^{\circ} \mathrm{C}$ and for 30 minutes with indigo.

- Wash fastness test was carried out on the dyed fabric according to International Organization for Standardization (ISO3) described by [13].

- Composite of $2 \mathrm{~cm}$ by $5 \mathrm{~cm}$ dimension of the dyed and undyed fabric sample was washed by agitation in $2 \mathrm{~g} / \mathrm{l}$ soap and $2 \mathrm{~g} / \mathrm{l}$ sodium carbonate solution at a liquor ratio of $40: 1$.

- The washing was carried out in a beaker placed in a water bath at $50^{\circ} \mathrm{C}$ for 30 minutes.

- Washfastness assessment involved comparing the degree of contrast between the originally dyed sample and the specimen tested (washed).

- ISO3 wash fastness grey scale was used for rating of the specimen under test which is a number of this grey scale contrast.

\subsubsection{Determination of Water of Imbibition}

The water of imbibition of the mercerized cotton/polyester fabrics were determined using the method stated by [14]. The fabrics were weighed and soaked in $250 \mathrm{ml}$ distilled water in a beaker for 5 minutes. It was removed and mopped with filter paper gently to remove excess water and it was then weighed again immediately. It was followed by progressive drying at $80^{\circ} \mathrm{C}$ in an oven for $5,10,15,20,25$ and 30 minutes. At each of these intervals, the weights of the sample were recorded using analytical balance. The temperature of the laboratory was recorded as $24 \pm 2^{\circ} \mathrm{C}$ during the experiment. The procedure was repeated three times for each sample and the average was calculated.

\section{Result And Discussion}

\subsection{Effects of alternative Scouring agents, Bleaching and Mercerizing Processes on the Physical} Properties of the Cotton/Polyester Blend Fabric.

The following changes were observed during and after the scouring, bleaching and mercerization Processes of the cotton/polyester blend fabric with alternative agents.

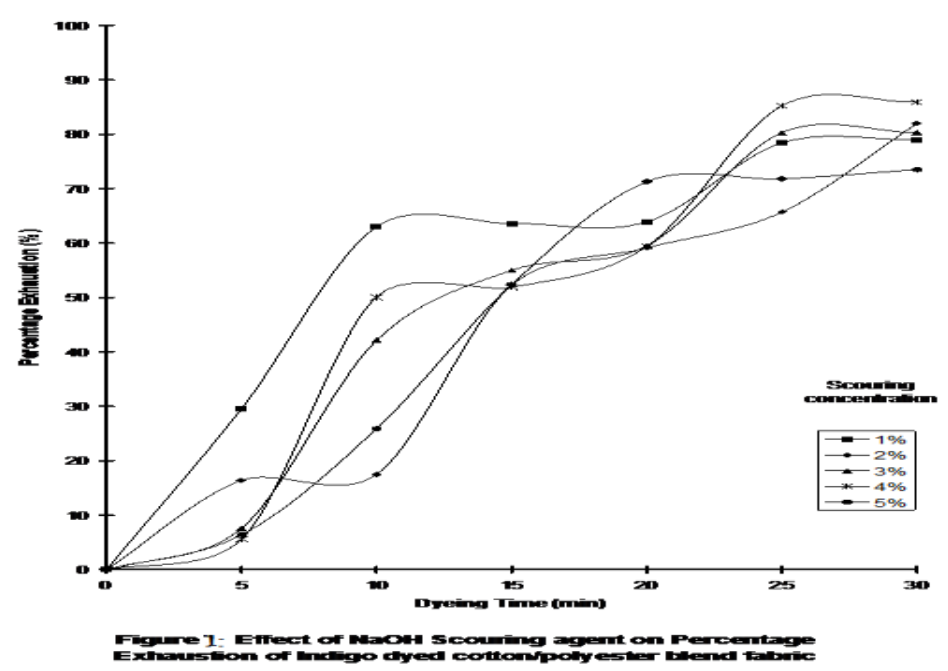



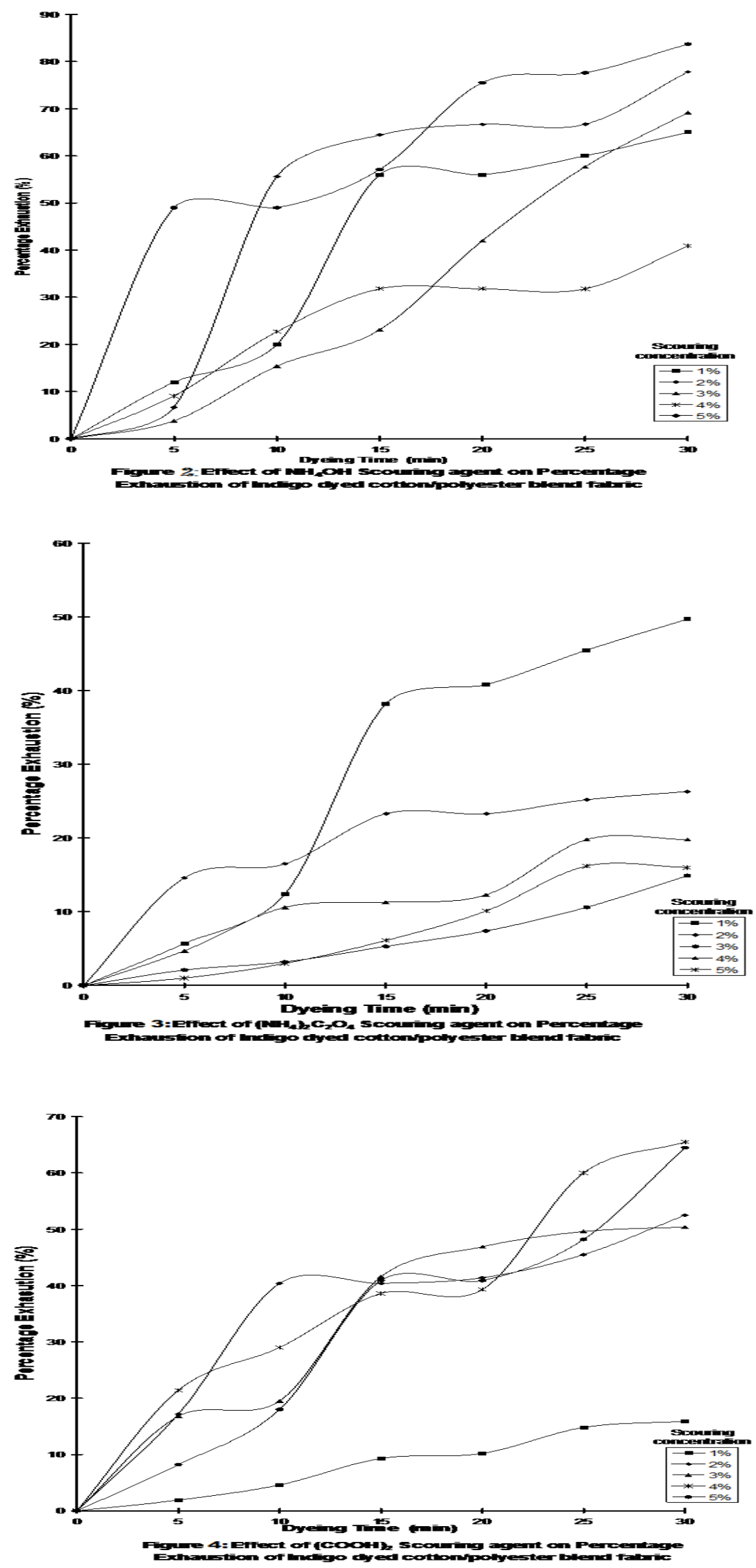

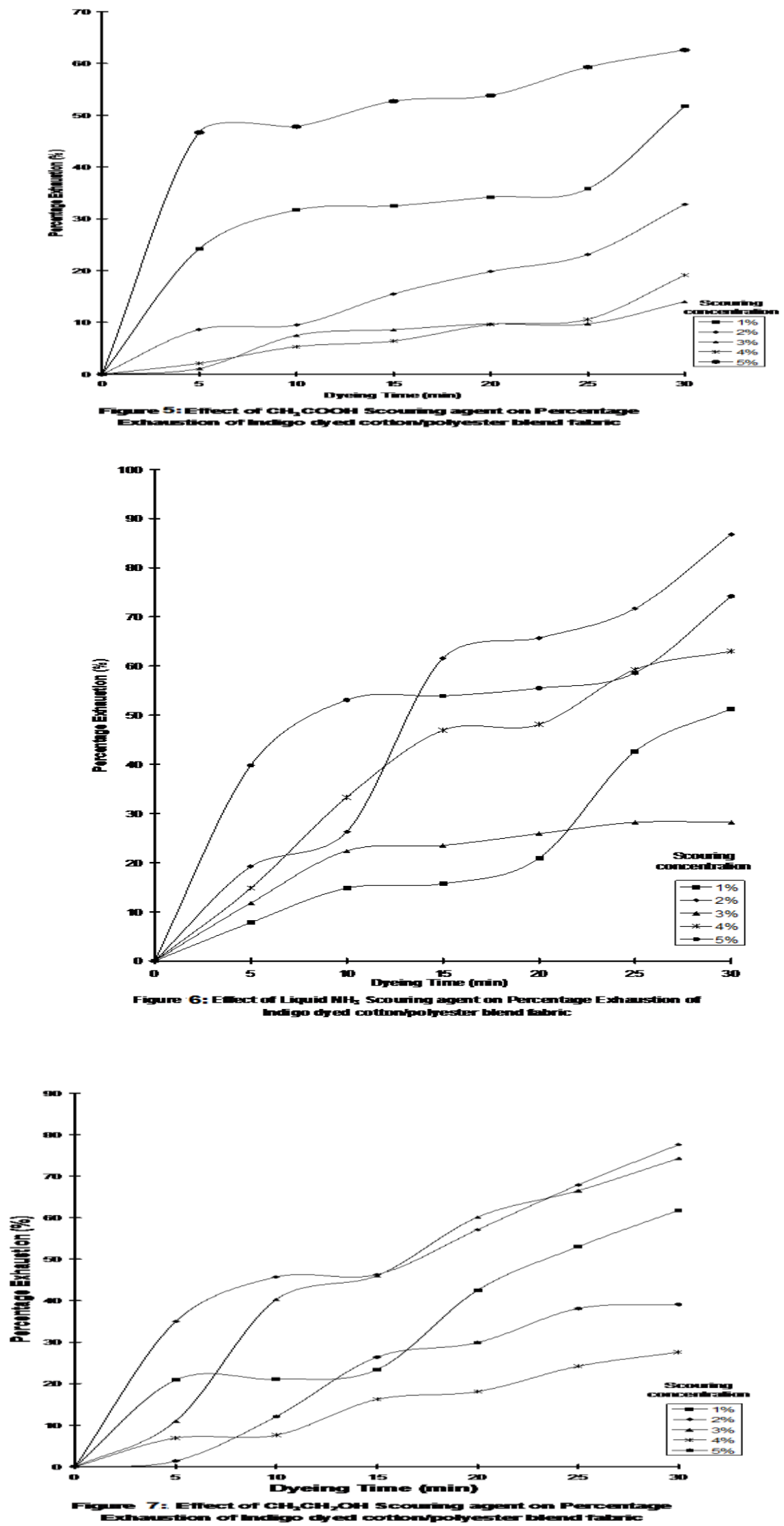
Table 1: Optimum percentage exhaustion of the effect of Scouring Agents on indigo dyeing process of mercerized cotton/polyester blend fabric

\begin{tabular}{lll}
\hline Scouring Agent & Concentration of scouring Agent (\%) & Percentage exhaustion (\%) \\
\hline Liquid $\mathrm{NH}_{3}$ & 2 & 86.8 \\
$\mathrm{NaOH}$ & 4 & 85.9 \\
$\mathrm{NH}_{4} \mathrm{OH}$ & 5 & 83.7 \\
$\mathrm{CH}_{3} \mathrm{CH}_{2} \mathrm{OH}$ & 2 & 77.6 \\
$(\mathrm{COOH})_{2}$ & 4 & 65.5 \\
$\mathrm{CH}_{3} \mathrm{COOH}$ & 5 & 62.6 \\
$\left(\mathrm{NH}_{4}\right)_{2} \mathrm{C}_{2} \mathrm{O}_{4}$ & 1 & 49.7 \\
\hline
\end{tabular}

\subsubsection{Scoured Samples}

During scouring, the scouring liquor or solution kept changing from colourless solution till after scouring to a slightly yellowish solution for all the alternative agents used and $\mathrm{NaOH}$ (control). This implies that purification has taken place. It is believed and is a known fact that during scouring with $2 \% \mathrm{NaOH}$, the oil and fat at boiling will be hydrolyzed to glycerol and alkali salt of the fatty acid (soap):

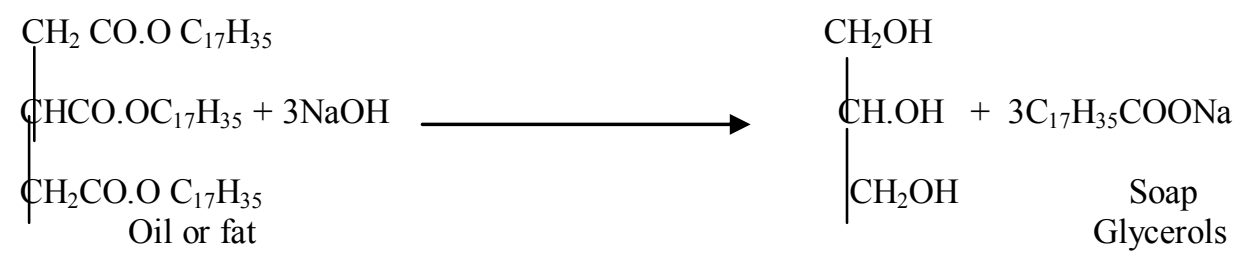

\section{Scheme 1: Hydrolysis of fat or oil by Sodium hydroxide}

The soaps formed at boiling; promote the emulsification of wax-like substance and unsaponifiable fats [2]. The alkali hydrolyzes proteins, and their molecules are broken along peptide links with the formation of alkalisoluble amino acids [2, 3 and 4]. Pectin and lignin substances are also hydrolyzed, their molecules are gradually destroyed and converted to soluble salts. Mechanically adhered dirt are loosened and held in suspension.

Thus it is expected and assumed that $\mathrm{NH}_{4} \mathrm{OH},\left(\mathrm{NH}_{4}\right)_{2} \mathrm{C}_{2} \mathrm{O}_{4}$, liquid $\mathrm{NH}_{3}$ will decompose the impurities in a similar manner. So also will $\mathrm{CH}_{3} \mathrm{COOH}, \mathrm{CH}_{3} \mathrm{CH}_{2} \mathrm{OH}$ and $(\mathrm{COOH})_{2}$ being organic components and the impurities are mostly organic components "like dissolves like".

At the end of the scouring process, the fabric samples were cleaner, texture improved and there were little decrease in the dimension of both length and width of the treated fabrics. This agrees with the reports of $[2,3$ and 4$]$ as the effect of scouring on fabrics and it is expected to improve the dyeing properties.

\subsubsection{Bleached Samples}

When the scoured samples were immersed in the bleaching solution of $\mathrm{NaClO}_{2}$, it was observed that the cloudy colour changed to slightly faint yellowish colour for all the fabric samples scoured with the various agents. This indicates that pigments and any remaining impurities were removed. This was confirmed by the appearance of the fabric samples. The fabrics became whiter and brighter than the unbleached after bleaching and drying.

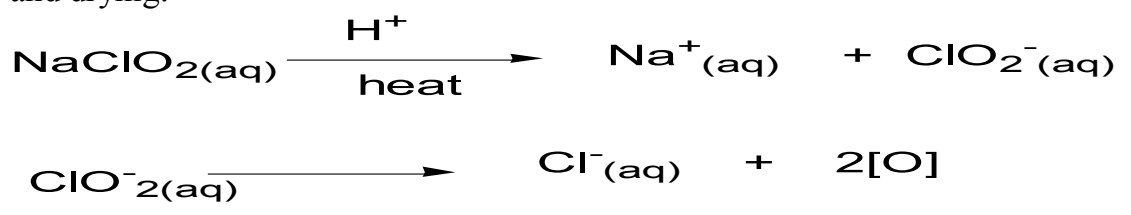

\section{Scheme 2: Formation of the atomic oxygen for bleaching with sodium chlorite}

\subsubsection{Mercerized Samples}

The bleached fabrics were mercerized with $22 \% \mathrm{NaOH}$. All the samples swells and gradually untwist and became smooth, soft, lustrous and glossy. This is reported by [2 and 15]. to be as a result of chemical, physicochemical and structural modifications on the fabric by the concentrated alkali. These changes are believed to result into improved properties. 


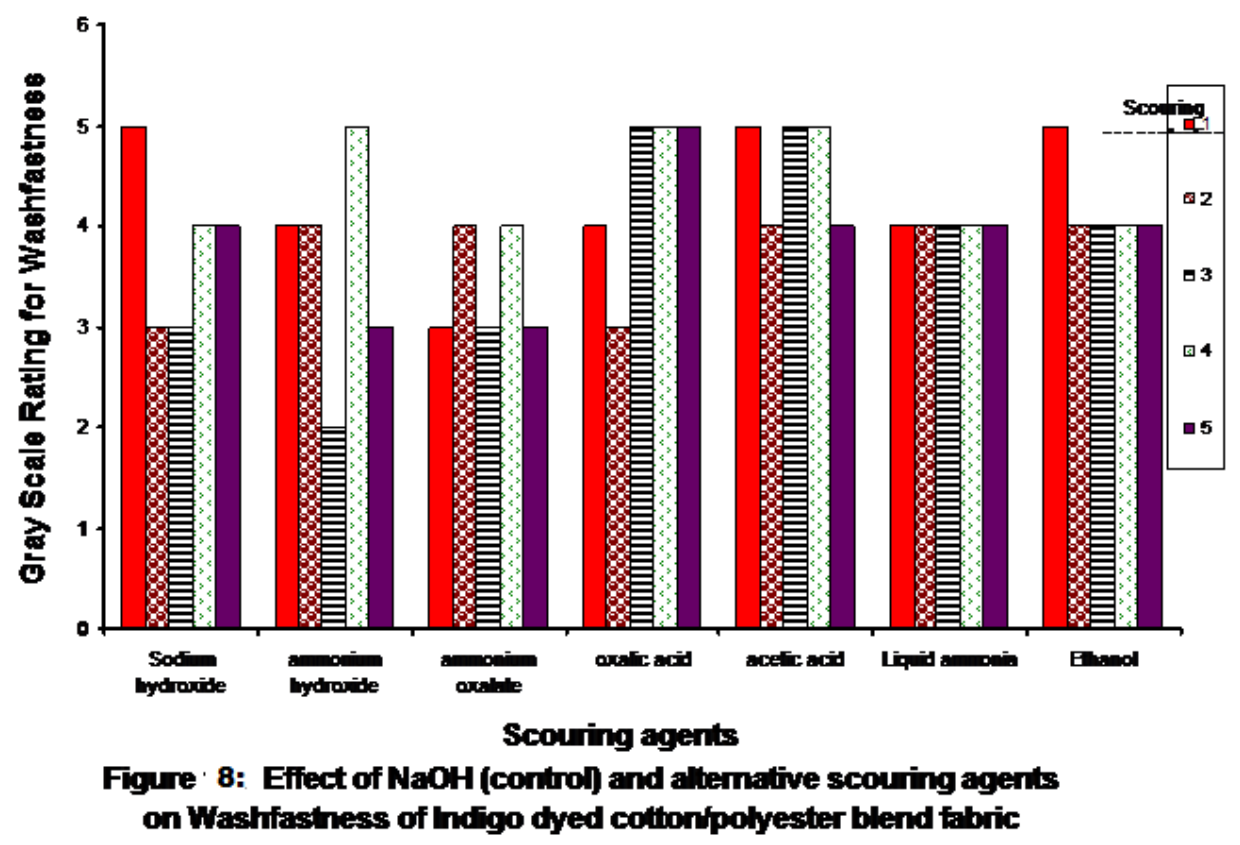

Table 2: Optimum Wash-fastness of the effect of Scouring Agents on Indigo Dyed Mercerized Cotton/Polyester Blend Fabric

\begin{tabular}{|c|c|c|c|c|}
\hline Scouring Agent & $\begin{array}{l}\text { Concentration of scouring } \\
\text { Agent }(\%)\end{array}$ & $\begin{array}{l}\text { Grey scale } \\
\text { washfsatness } \\
\end{array}$ & rating for & Remark \\
\hline $\mathrm{CH}_{3} \mathrm{COOH}$ & 1,3 and 4 & 5 & & Excellent \\
\hline$(\mathrm{COOH})_{2}$ & 3,4 and 5 & 5 & & Excellent \\
\hline $\mathrm{CH}_{3} \mathrm{CH}_{2} \mathrm{OH}$ & 1 & 5 & & Excellent \\
\hline $\mathrm{NH}_{4} \mathrm{OH}$ & 4 & 5 & & Excellent \\
\hline $\mathrm{NaOH}$ & 1 & 5 & & Excellent \\
\hline LIQUID NH$_{3}$ & $1-5$ & 4 & & Very good \\
\hline$\left(\mathrm{NH}_{4}\right)_{2} \mathrm{C}_{2} \mathrm{O}_{4}$ & 2 and 4 & 4 & & Very good \\
\hline
\end{tabular}

3.2 Effects of $\mathrm{NaOH}$ (control) and Alternative Scouring Agents on Dyeing Properties of Mercerized Cotton/Polyester Blend Fabric.

The alternative scouring agents and the control affected the degree of percentage exhaustion of indigo dye and wash-fastness of the indigo dyed cotton/polyester blend fabric in the following trend.

\subsubsection{Effect of Scouring Agents on Degree of percentage Exhaustion of Indigo Dyed Cotton/Polyester Blend Fabric}

With reference to Figures 1-7, the degree of exhaustion increased as the time of dyeing increased. However, there is no regular trend with respect to the various scouring concentrations of the agents. The interesting observation is that dye up take has been affected after the scouring process by the scouring agents at percentage far above average except for $1 \%\left(\mathrm{NH}_{4}\right)_{2} \mathrm{C}_{2} \mathrm{O}_{4}$ scoured fabric sample with $49.7 \%$ degree of exhaustion. This signifies that the impurities that impede dye adsorption were removed [2] providing pores (amorphous) for dye adsorption. 2\% liquid $\mathrm{NH}_{3}$ scoured fabric recorded the highest degree of exhaustion (86.8\%) followed by $4 \% \mathrm{NaOH}$ Control (85.92\%). $5 \% \mathrm{NH}_{4} \mathrm{OH}(83.7 \%)$ closely competed with the control, while $2 \% \mathrm{CH}_{3} \mathrm{CH}_{2} \mathrm{OH}(77.6 \%)$ competed with the control (Table 1). $4 \%(\mathrm{COOH})_{2}$ and $5 \% \mathrm{CH}_{3} \mathrm{COOH}$ optimally recorded $65.5 \%$ and $62.6 \%$ degree of exhaustion respectively. This somehow shows that the alkaline agents recorded higher degree of exhaustion (83.7\%-86.8\%). This may mean that the alkaline agents saponifies and hydrolyses the impurities far better than the other agents. There by having more amorphous regions for dye adsorption.

\subsubsection{Effect of Scouring Agents on Wash-fastness of Indigo dyed Cotton/Polyester Blend Fabric}

Colour retention after dyeing is important parameters in textiles [13]. Colour is often the primary consideration when purchasing clothing and household textiles. When the colour fades or streaks, items are discarded before they are worn out. 
The scouring process has shown an excellent improvement in the dye adsorption and retention. With reference to Figure 8 and Table 2, it is observed that the organic alternative agents $(1 \%, 3 \%$ and $4 \%$ $\mathrm{CH}_{3} \mathrm{COOH}, 3 \% 4 \%$ and $5 \%(\mathrm{COOH})_{2}$ and $\left.1 \% \mathrm{CH}_{3} \mathrm{CH}_{2} \mathrm{OH}\right)$ including $4 \% \mathrm{NH}_{4} \mathrm{OH}$ strongly competed with the control $(\mathrm{NaOH})$ with a grey scale rating of 5, indicating excellent wash-fastness. In the actual sense, this implies that despite their lower degree of exhaustion (that is the organic alternative agents), the dye adsorbed were properly fixed in the provided amorphous region of the cotton/polyester fabric. This also means that the organic alternative agents are better scouring agents, removing the impurities and creating permanent pores (amorphous region). This permanent space allowed for better intermolecular hydrogen bond and Vander Wa'als force between the dye and the fabrics. Thus the dye molecules were bonded, therefore improving resistance to washing. This indicates that, there is no loss in intensity of colour suggesting insignificant change in hue. This is as a result of insignificant breakdown of colourant itself inside the fabric.

Optimum wash-fastness for 1-5\% liquid $\mathrm{NH}_{3}$ and 2-4\% $\left(\mathrm{NH}_{4}\right)_{2} \mathrm{C}_{2} \mathrm{O}_{4}$ recorded a grey scale rating of 4 respectively which is referred to as a very good rating. This implies that there is a slight loss in depth and change in hue of the colour. It also has a slight change in contrast. Liquid $\mathrm{NH}_{3}$ recorded the highest percentage exhaustion, but part of the adsorbed dye suffered little breakdown of colourant during washing. This may imply that artificial amorphous regions might have been created and the adsorbed dye molecules were not fixed to the fabric. Therefore the unfixed dye remains on the surface of the fabric, giving it a falsified deeper shade. On washing the unfixed dye is detached from the surface of the fabric and only those that are properly fixed remain on the fabric after washing.

$2 \%$ and $4 \%\left(\mathrm{NH}_{4}\right)_{2} \mathrm{C}_{2} \mathrm{O}_{4}$ also gave an optimum grey scale rating for wash-fastness of 4 that is, very good. This agrees with the observed percentage exhaustion which is below average. This implies that the dye adsorbed were not all retained because of improper fixing in the available pores.
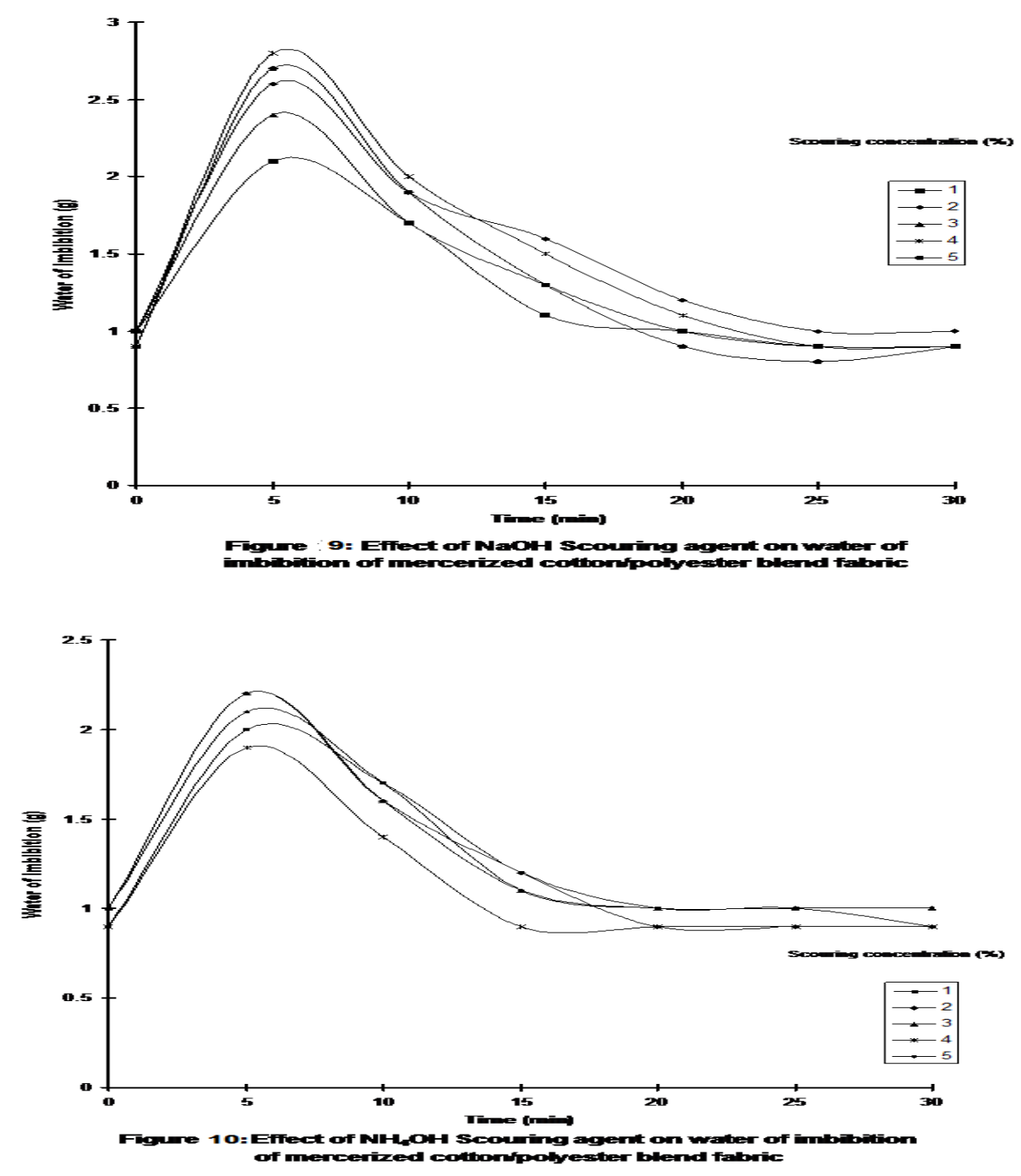

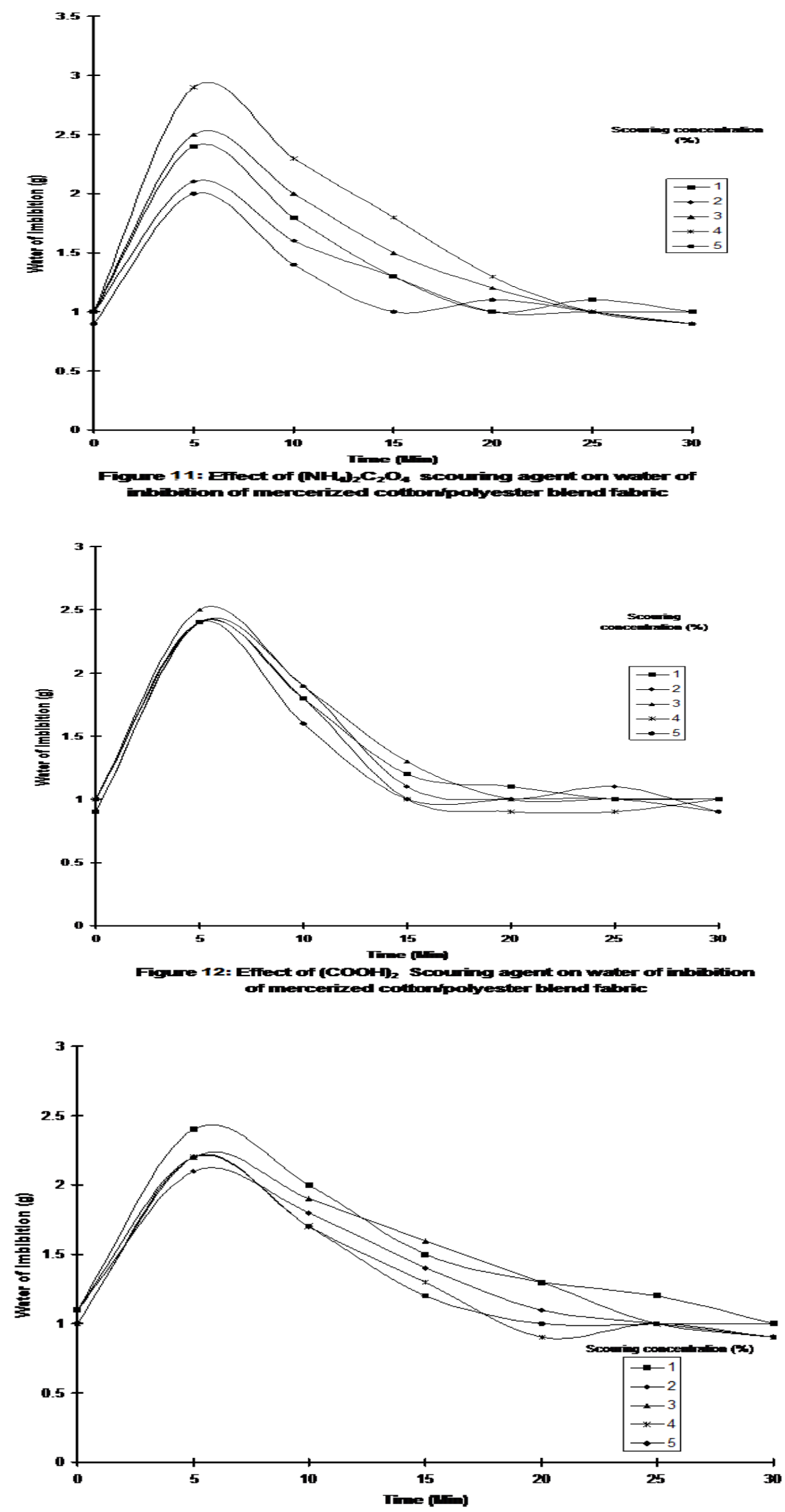

Figure 13: Efrect of $\mathrm{CH}_{3} \mathrm{COOH}$ Scouring agent on waber of inbibition of mercerized cothonfpobyester blend fahric 


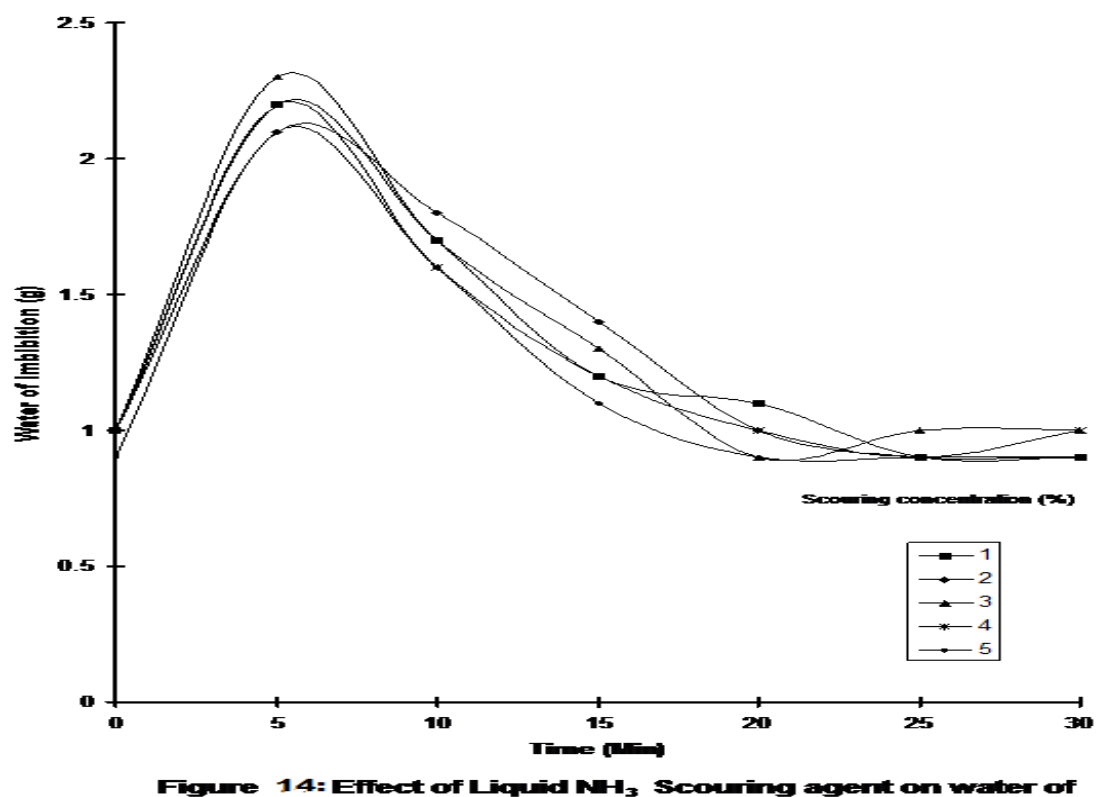

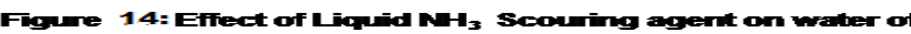

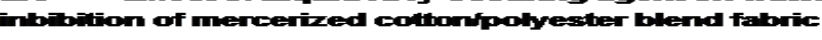

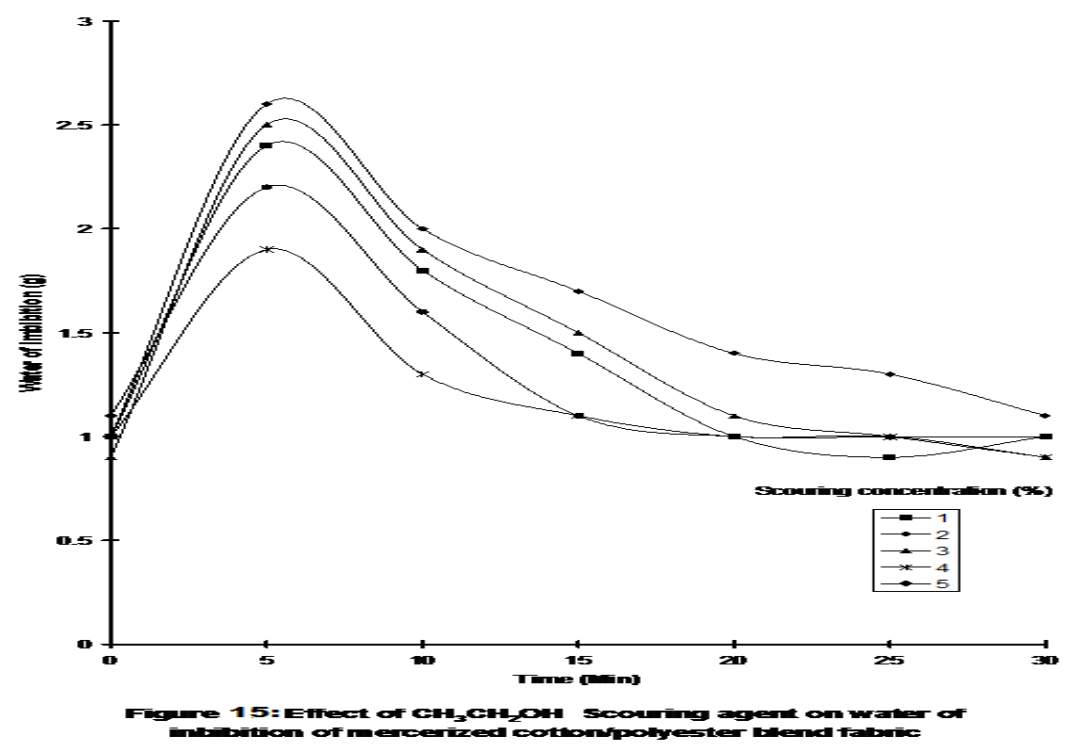

Table 3:Optimum Water of Imbibition of the effect of Scouring Agents on Mercerized Cotton/Polyester Blend Fabric

\begin{tabular}{lll}
\hline Scouring Agent & Concentration of scouring Agent (\%) & Water of imbibition (g) \\
\hline$\left(\mathrm{NH}_{4}\right)_{2} \mathrm{C}_{2} \mathrm{O}_{4}$ & 4 & 2.9 \\
$\mathrm{NaOH}$ & 4 & 2.8 \\
$\mathrm{CH}_{3} \mathrm{CH}_{2} \mathrm{OH}$ & 2 & 2.6 \\
$(\mathrm{COOH})_{2}$ & 3 & 2.5 \\
$\mathrm{CH}_{3} \mathrm{COOH}$ & 1 & 2.4 \\
$\mathrm{Liquid} \mathrm{NH}_{3}$ & 1 & 2.3 \\
$\mathrm{NH}_{4} \mathrm{OH}$ & 2 and 3 & 2.2 \\
Untreated & & \\
\hline
\end{tabular}




\subsubsection{Effect of Alternative Scouring Agents and control $(\mathrm{NaOH})$ on Water of Imbibition of Mercerizing Cotton/Polyester Blend Fabric}

According to [16], water of imbibition measures the quantity of water that is absorbed under specified conditions and temperature. From Figures 9-15 there is improvement in water of imbibition for the scoured cotton/polyester blend fabrics. This suggests that the scouring process has effected proper removal of impurities occupying the amorphous region, there by increasing its water adsorption capacity. It was also observed that, there is gradual decrease in the water imbibed by all the fabric samples as the drying time increase. The gradual decrease implies that the scoured fabrics have retention property of the imbibed water even under oven drying condition. This implies a promising dyeing property. Table 3 shows the optimum water of imbibition of the scouring agents for cotton/polyester blend fabric. The values ranged competitively from $2.9-2.2 \mathrm{~g}$ for all the scouring agents. $4 \%\left(\mathrm{NH}_{4}\right)_{2} \mathrm{C}_{2} \mathrm{O}_{4}$ recorded the highest followed by $4 \% \mathrm{NaOH}$ scoured sample fabric. This also agrees with [17] work on Kenaf fibre. The least value (2.2g) was recorded by $2 \%$ and $3 \% \mathrm{NH}_{4} \mathrm{OH}$ scoured fabric.

Moisture affects the manner in which fabric behaves in different humidity conditions. For example at high moisture content, properties such as tensile strength, breaking load, breaking strength, and breaking extension increases [18]. This is due to the presence of hydrogen bonding between water molecules and the molecules of the fabrics (cellulose, etc). It therefore finds it difficult to break away [19]. This means that these scouring agents will favour improvements in mechanical properties of the fabric when wet.

\section{Conclusion:}

The effects of alternative scouring agents on the dyeing properties of treated cotton/polyester blend fabric in some cases are much better than those of the industrial and commercial scouring agents (NaOH). Also in some cases these alternative agents compared favorably with the control.. Therefore, these alternative agents could be employed as scouring agents industrially and commercially.

It is recommended that the alternative scouring agents be adapted in the textile industry and commercially.

\section{Acknowledgement:}

This work would not have been possible without the sponsorship I received from Ocean Energy Nigeria Limited, Knorr 296, Ozumba Mbadiwe Street Victoria Island Lagos NIgeria. I am deeply indebted to the company for taking interest in research and development.

\section{References}

[1] Anonymous, the Columbia Encyclopedia. Retrieved March, 112010 from www.wikipedia,the free Encyclopedia , 2007

[2] F.Sadov, M.Kauchagin, and A.Matestry,. Chemical Technology of Fibrous Materials. MIR Publishers, Moscow. 1973, 22-44, 126300 ,

[3] F.Darinka, G.Darko, and S.H. Zoran, Fibres and Textiles, Eastern Europe, 16 (2), 2000, 67-72,

[4] J. E. Safra, S.Constantine, J. Yannias, and E.Goulk, Encylopedia Britanica $15^{\text {th }}$ Edition. 9(10), 2004, 170-189.

[5] E.R. Trotman, Dyeing and Chemical Technology of Textiles Fibers. Charles Griffin Co. Ltd. London, $4^{\text {th }}$ Edition. 1975, 319-329..

[6] K.Kunttou, S. Hongyo, S. Maeda,.and K. Mishi, Dyeing Polyester Fabrics with Indigo. Textiles Research Journal. 56(9), 2005 1-4.

[7] M.R. Harzel, and X. A Hsiet, "Effect of $\mathrm{pH}$ in the root Evrironment from plant roots" $4^{\text {th }}$ edition Book (Cole Publishing company Moterney, California, 1998, 120-620.

[8] SCHER Scientific Committee on Health and Environmental Risks, Targeted Risk Assessment on sodium hydroxide and environment. European Commission on Health and consumer protection Directorate, 2006, 4 - 6

[9] D.E.A, Boryo J.O, Ajayi N.S Gin and M.D. Yusuf): The Effects of Sodium Hydroxide and Ammonium Oxalate on Mucilaginous Matters of Kinaf Fibers (Hibiscus Canabinus) Paper Presented at the $22^{\text {nd }}$ Annual National Conference of chemical Society of Nigeria at Hill Station Hotel Jos, Nigeria.1999, 30-35.

[10] D.E.A.Boryo, K.A, Bello, A.Q.Ibrahim, A.I, F.I Ezeribe Omizegba. and P.U. Offodile. Effect of alternative scouring agents on mechanical properties of cotton/polyester blend fabric. Paper presented at annual technical conference/agm of Polymer Institute Of Nigeria at best western Homeville Hotel, Evbuowman street off Sapele road, Etete. Benin city, 2012

[11] C.H. Giles. A Laboratory Course in Dyeing. The Society of Dyers and Colourist, Bradford, $3^{\text {rd }}$ Edition $1974,35-112$.

[12] N.S.Gin, , K.A. Bello and A.Q. Ibrahim. Effects of Electrolyte on the Exhaustion and Affinity of Reactive Dyes. (Science Forum 1). Journal of Pure and Applied Science. 9 (1), 2006, 66-73.

[13] Stevens, C.B. The Dyeing of Synthetic Polymer and acetate FIbres, The dyers Company publications trust, Yockshire England, 1979, 53-61.

[14] J.O. Ajayi and K.A. Bello. Colour and Textiles Chemistry. $1^{\text {st }}$ Ed., 2005, $5-11$.

[15] A.B. Moji,. Polymers: The Chemistry and Technology of Modern Material. Yaba College of Technology, Yaba, Lagos, Concept Publications Ltd, 2000, $193-268$.

[16] M,Rouusselle, D.P. Thibodeaux and A.D. French. "Cotton Fibre Properties and Moistures: Water of Imbibition". Textiles Research Journal; Retrieved June 6, 2005 from www.findarticle.com, 2005

[17] D.E.A. Boryo. Evaluation of Chemical Damage of Kenaf(Hibiscus cannabinus) Fibres During Processing. Unpublished M.Sc.Thesis. ATBU Bauchi Nigeria, 1999

[18] J.Robert and McGill. Measurement and Control in Paper Making. Adam Hilger Ltd, Techno House, Redcliff way, Bristool, BSI 6NX, Wolverhampton,Wr 100 JA, England, 1980. 311 - 312.

[19] A. I. Ezeribe, D.E.A.Boryo, K.A.Bello, and H.M. Adamu. Effect of varying catalyst mass and degree of substitution on the rheological properties of melamine formaldehyde resin syrup. The Yankari Journal, 6, $2010152-156$ 